\title{
AIR TEMPERATURE STRATIFICATION NEAR THE GROUND IN RELATION WITH ATMOSPHERIC CIRCULATION WITHIN THE SIRET CORRIDOR
}

\author{
Lucian SFIC $\breve{A}^{1}$, Diana HUSARIU ${ }^{1}$, Pavel ICHIM ${ }^{1}$ \\ Andrei-Ion NITA ${ }^{2}$
}

DOI: 10.24193/AWC2020_11

\begin{abstract}
The study presents the results of 3 years of measurements on air temperature in the lowest part of the Siret Corridor, on a $50 \mathrm{~m}$ high vertical profile. Using the hourly and daily values of air temperature from these 2 observation points, the main features of air temperature above the surface were described. Also, the study explores the connection between the atmospheric circulation and the air temperature stratification in the Siret Corridor. In view of this, an atmospheric circulation classification was derived from COST-733 software and was corroborated with observational data. In this way, the synoptic conditions associated with different types of air temperature stratification in the study region were identified. The results indicate that the temperature inversions became prevalent at annual level concerning minimum air temperature, representing the most common temperature stratification during winter mornings, but they develop even from the end of the summer. From a dynamic point of view, besides the well-known role of high pressure centers, other types of synoptic conditions have been identified as favorable for the occurrence of air temperature inversions.
\end{abstract}

Keywords: temperature profile, atmospheric circulation, air temperature inversion, Siret Corridor.

\section{INTRODUCTION}

The North-Eastern part of Romania represents the region most prone to display stable air temperature stratification in our country. This aspect is reflected precisely by the set of air temperature distribution maps from the Climatological Atlas of Romania (1966) which indicated for the first time that the lower part of the valleys within this region (Siret, Bârlad, Prut) are colder than, the hilly region around them during the winter months.

\footnotetext{
${ }^{1}$ Faculty of Geography and Geology, Alexandru Ioan Cuza University of Iași, sfical@yahoo.com nicuriuc@yahoo.com

${ }^{2}$ National Meteorological Administration, nitaandru@gmail.com
} 
This characteristic was detailed in the following climatic regional studies. In this line, Apăvăloae et al. (1975) estimated the air temperature relative inversion frequency at $35 \%$ for mean values in the Fălticeni Plateau. A similar analysis performed by Mihăilescu et al. (1980), using daily data, assessed the frequency of air temperature inversions in the Subcarpathian region of Moldova between TârguOcna and Adjud by $30 \%$, with a maximum during winter, but also occurring during all months(with a minimum by $15 \%$ for June-August). Recently, Ichim et al. (2013), using hourly data, indicated that the Siret valley is prone to air temperature inversion occurrence in Moldova. These authors measured for 2013, using hourly data, a relative frequency of air temperature between Roman weather station and the upper part of Dealu Mare - Hârlău by $25 \%$.

Due to its vast lateral extension and due to the high hills from its surroundings the central sector of Siret valley represents implicitly a very important region for the occurrence of air temperature inversion in Romania outside of the mountain area. Sfîcă et al. (2015), using daily data, assessed the frequency of air temperature by $40 \%$ between Roman and Strunga weather stations for 1991-1998 (75\% based on minimum air temperature and $18 \%$ based on maximum air temperature). Obviously, the intense air temperature inversions occurring in this region represents the cause for the very low air temperature recorded here, as $-35.0^{\circ} \mathrm{Con} 14$ of January 1893 at Păncești-Dragomirești weather station (Andrei, 1937).Also, at the weather station in Roman, situated approximately $50 \mathrm{~m}$ above Tămășeni observation point, which is used in this study, the absolute minimum air temperature recorded between $1961-2005$ was $-32.7^{\circ} \mathrm{C}$ (Sfîcă et al., 2015). Overall, the Siret Corridor represents an important cold air reservoir during the cold semester (Apostol, 2004).

In this line, in order to better understand the air temperature distribution at local scale in the North-Eastern part of Romania, a measurement campaign was initiated in 2015 based on 2 observation points, aiming at the description of air temperature conditions on a vertical profile in the proximity of the ground within the lowest part of the Siret valley near the weather station in Roman.

\section{DATA AND METHODS}

The first monitoring point was installed in the lower area of the Siret valley (Tămășeni, $187 \mathrm{~m}$ - Tămășeni Ground in the current study) under classical shelter conditions. The second one was installed in the tower of the church from the same village in open air conditions at a height of $50 \mathrm{~m}$ above ground level, using the same classical weather shelter (Tămășeni Tower). It is noteworthy to underline that the horizontal distance between the two points is under $10 \mathrm{~m}$. These two points offered us the possibility to assess the air temperature characteristics in the lowest part of Siret valley - not covered by any official weather station - but also to describe the air temperature conditions between ground level and $50 \mathrm{~m}$ in altitude, where the major variations near the ground are to be observed (Geiger, 1961). Based on hourly data, 
the daily, monthly, seasonal and annual means of air temperature were calculated and analyzed. The warm semester was considered the one between April and September, with the cold semester being between October and March.

For comparison, we analyzed hourly meteorological data from Roman weather station, situated at less than $5 \mathrm{~km}$ from the observation points, on the left large developed terrace of Siret River. This weather station is situated at $50 \mathrm{~m}$ relative altitude above Tămășeni observation point $(187 \mathrm{~m})$ and at an absolute altitude near the altitude of the church tower observation $(237 \mathrm{~m}$ at Roman and 218 at the church tower- Fig. 1). Data from Roman weather station were taken from meteomanz.com.

In order to assess the atmospheric circulation conditions, an objective classification for atmospheric circulation types called Gross Wetter Types (GWT) based on threshold criteria was used (Beck, 2000). It was constructed using the daily mean-sea-level-pressure at 12 UTC (MSLP) data from ECMWF Era-Interim reanalysis (Dee et al., 2011) and cost733class software (Philipp et al., 2010). The basic idea for the GWT classification is to characterize the circulation patterns in terms of varying degrees of zonality, meridionality and vorticity of the large scale mean sea level pressure field (Beck et al., 2007).

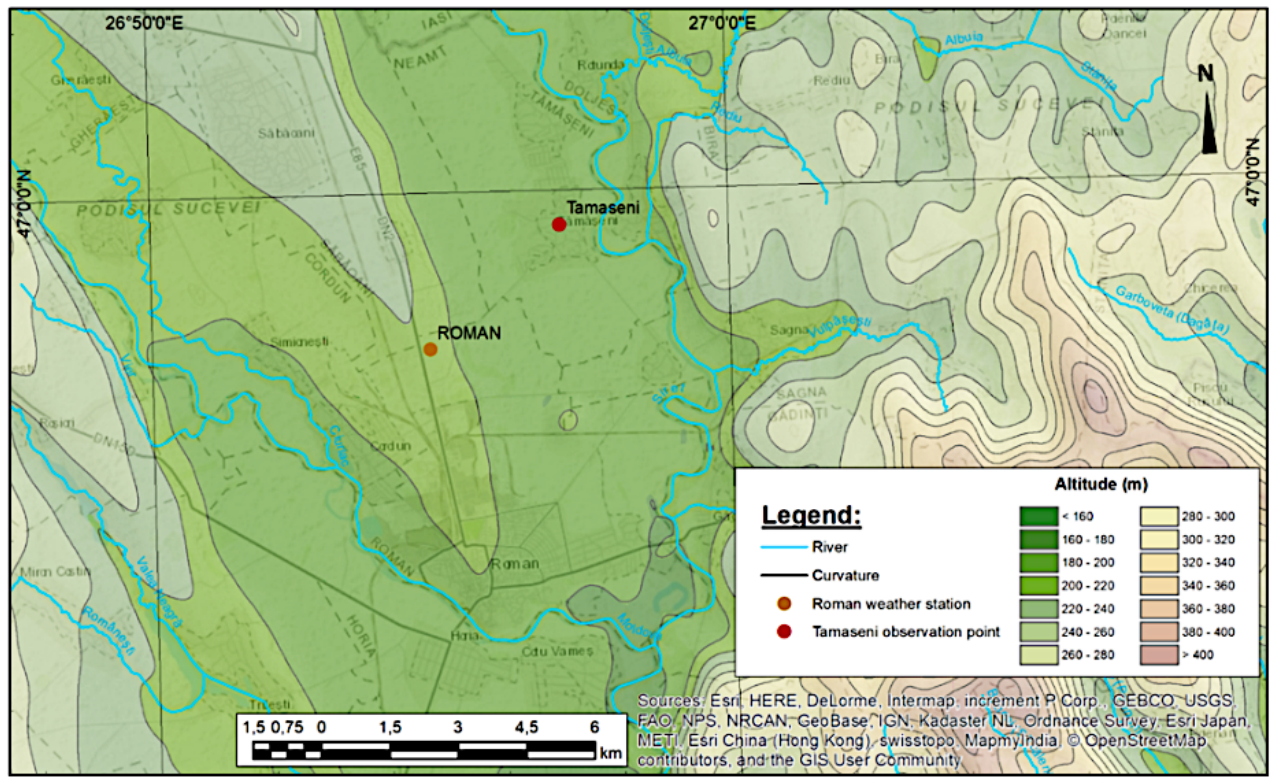

Fig. 1. Physico-geographical map of the study region with the location of the observation points

This way, an objective classification was conceived with 18 atmospheric circulation types, as described in Fig. 2. This includes mostly cyclonic circulation types (types 1-8), mostly anticyclonic circulation types (as 9-16) and Central Low/High types (17 and 18). The classification was constructed for the 1979-2018 period, and used for our study period (2015-2018). 


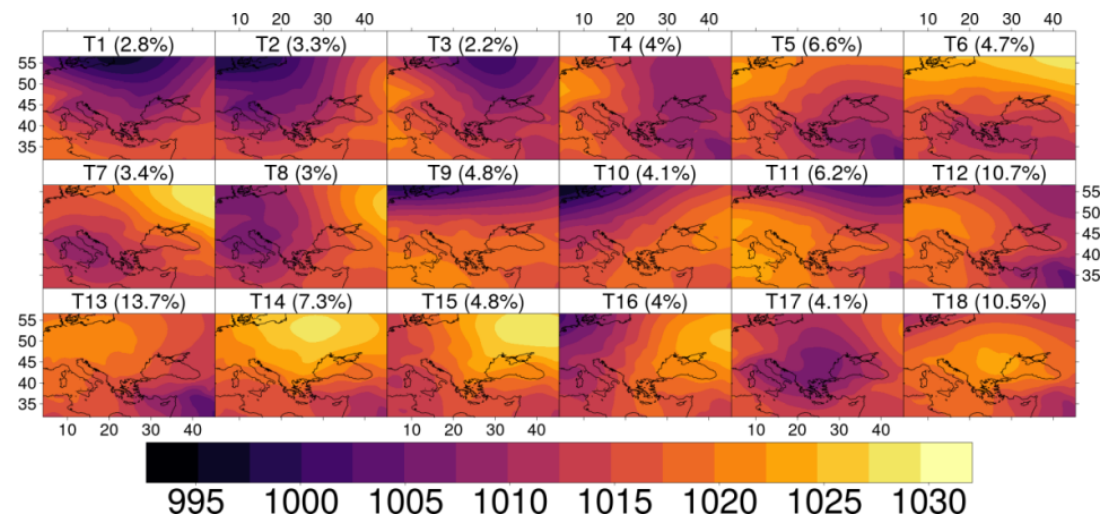

Fig. 2. Types of atmospheric circulation according to the Gross Wetter Types classification for the region of Romania, based on Sea Level Pressure (hPa)

Using the daily air temperatures data, we selected the days with temperature inversions and analyzed the synoptic patterns associated with these conditions.

\section{RESULTS AND DISCUSSIONS}

The air temperature general characteristics, over the study area, for the analyzed period, are described in details in Table 1 . It is to be observed that the mean air temperature in the 3 points is similar $\left(10.5^{\circ} \mathrm{C}\right)$, but despite this uniformity important differences are present at monthly level. In this way, from May to August the air temperature is higher, with $0.3-0.4^{\circ} \mathrm{C}$ in Tămășeni Ground comparing with Roman weather station or with Tămășeni Tower. On the contrary, from September to January the mean air temperature is lower with $0.5-0.9^{\circ} \mathrm{C}$ between the same points (Fig. 3). This annual pattern of monthly air temperature differences represents the insolation season during the summer and the prevalent radiative conditions specific for the autumn and winter seasons, when air temperature inversions are more frequent. This is reflected in the mean amplitude of air temperature which is higher on the valley $\left(25.7^{\circ} \mathrm{C}\right.$ at Tămășeni Ground), than on the medium terrace of Siret river $\left(23.9^{\circ} \mathrm{C}\right.$ at Roman weather station).

The local differences in air temperature distribution are well underlined by the extreme values of air temperature recorded in the region. The lowest air temperature was recorded at Tămășeni Ground $\left(-23.5^{\circ} \mathrm{C}\right), 1.3^{\circ} \mathrm{C}$ below the value recorded at Roman weather station. This shows the differences imposed by the air temperature inversions between the lower part of the Siret valley and the medium river's terrace, where Roman weather station is situated. On the contrary, for the maximum air temperature recorded in August, the value at Tămășeni Ground $\left(39.1^{\circ} \mathrm{C}\right)$ is $1.6^{\circ} \mathrm{C}$ higher than the value from Roman weather station. 
Table 1. Monthly mean air temperature at Roman weather station and Tămășeni (March 2015 - February 2018);

\begin{tabular}{|c|c|c|c|c|c|c|c|c|c|c|c|c|c|c|c|}
\hline & & & I & II & III & IV & $\mathrm{V}$ & $\mathrm{VI}$ & VII & VIII & IX & $X$ & XI & XII & Year \\
\hline \multirow{5}{*}{ 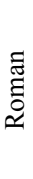 } & \multirow{5}{*}{ 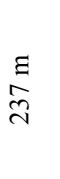 } & Txx & 12.1 & 19.5 & 23.2 & 29.6 & 29.0 & 33.3 & 36.2 & 3.5 & 36.5 & 26.7 & 21.6 & 16.4 & 37.5 \\
\hline & & Txm & 10.4 & 14.0 & 20.9 & 27.0 & 28.8 & 32.7 & 34.7 & 36.1 & 33.1 & 24.4 & 19.3 & 13.9 & 24.6 \\
\hline & & $\mathrm{Tm}$ & -3.0 & 0.6 & 6.5 & 10.9 & 16.0 & 20.2 & 21.9 & 21.8 & 18.0 & 9.4 & 5.0 & 1.8 & 10.7 \\
\hline & & $\mathrm{Tn}$ & -18.1 & -15.1 & -3.4 & -1.2 & 3.5 & 8.9 & 10.5 & 8.5 & 3.7 & -2.1 & -4.5 & -8.2 & -1.5 \\
\hline & & Tnn & -20.2 & -22.2 & -4.7 & -0.6 & 1.2 & 7.7 & 10.7 & 6.4 & 0.3 & -1.8 & -7.4 & -9.2 & -22.2 \\
\hline \multirow{10}{*}{ 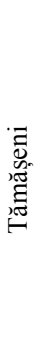 } & \multirow{5}{*}{ 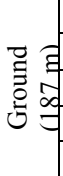 } & Txx & 12.2 & 20.5 & 24.8 & 30.8 & 31.9 & 34.3 & 38.5 & 39.1 & 37.9 & 26.8 & 21.7 & 12.9 & 39.1 \\
\hline & & Txm & 10.5 & 15.4 & 22.7 & 28.3 & 30.9 & 34.0 & 35.9 & 37.8 & 35.0 & 25.1 & 18.9 & 11.8 & 25.5 \\
\hline & & $\mathrm{Tm}$ & -3.5 & 0.3 & 6.2 & 10.9 & 16.1 & 20.7 & 22.2 & 22.2 & 17.3 & 8.5 & 4.3 & 0.8 & 10.5 \\
\hline & & $\mathrm{Tn}$ & -18.5 & -16.1 & -4.8 & -2.4 & 2.7 & 8.4 & 9.7 & 7.6 & 2.3 & -2.9 & -5.7 & -9.0 & -2.4 \\
\hline & & Tnn & -19.0 & -23.5 & -7.1 & -2.4 & 0.6 & 7.1 & 9.6 & 4.9 & -1.2 & -2.8 & -8.6 & -10.9 & -23.5 \\
\hline & & Txx & 12 & 19.1 & 22.7 & 29.8 & 29.5 & 33.8 & 36.4 & 37.4 & 37.7 & 27.9 & 20.6 & 12.4 & 37.7 \\
\hline & & Txm & 10.3 & 15.8 & 21.0 & 27.0 & 29.0 & 33.1 & 35.1 & 36.1 & 33.9 & 25.9 & 18.4 & 11.3 & 24.7 \\
\hline & $\dot{\Delta}$ & $\mathrm{Tm}$ & -3.3 & 0.3 & 6.0 & 10.8 & 15.9 & 20.3 & 22.0 & 21.9 & 17.8 & 9.1 & 4.5 & 1.4 & 10.5 \\
\hline & 3 & $\mathrm{Tn}$ & -17.1 & -14.1 & -2.5 & -0.7 & 4.8 & 10.0 & 11.3 & 9.4 & 4.4 & -1.4 & -4.0 & -8.7 & -0.7 \\
\hline & & Tnn & -18.4 & -20.7 & -4.2 & -0.9 & 2.6 & 8.5 & 10.9 & 7.7 & 0.5 & -1.7 & -7 & -9.5 & -20.7 \\
\hline
\end{tabular}

*Tm - mean, Txm - maximum mean, Txx - maximum high, Tnm - minimum mean, Tnn - minimum low

From a microclimatic point of view, we can observe that in winter the air temperature at the level of church tower is similar with that of Roman weather station, while in winter, as effect of more frequent air temperature inversions, they are $0.3-0.5^{\circ} \mathrm{C}$ lower.

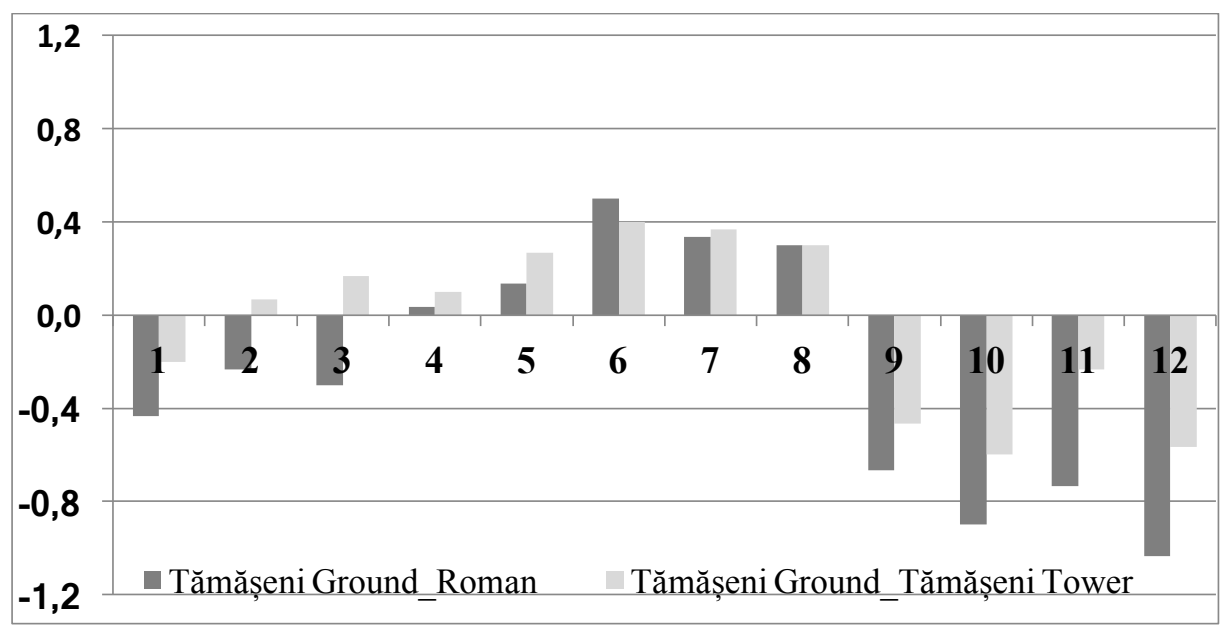

Fig. 3. Differences in monthly mean air temperature $\left({ }^{\circ} \mathrm{C}\right)$ between Tămășeni Ground and Tămășeni Tower/Roman (March 2015 - February 2018)

The hourly data describe the daily regime of air temperature at annual and seasonal level in the Siret valley and in the lower part of the atmosphere until $50 \mathrm{~m}$ (Table 2). The maximum hourly air temperature is recorded around 02 PM local time $\left(15.9^{\circ} \mathrm{C}\right)$, while at the tower level the maximum is recorded one hour later $\left(14.8^{\circ} \mathrm{C}\right)$. The minimum hourly air temperature is recorded at both levels around 05 AM. 
In July the maximum hourly air temperature is recorded at $02 \mathrm{PM}\left(29.3^{\circ} \mathrm{C}\right)$ while at the tower level the inertial effect moves the maximum air temperature at $04 \mathrm{PM}\left(27.3^{\circ} \mathrm{C}\right)$. The minimum air temperature in July is recorded at $04 \mathrm{AM}$ $\left(15.4^{\circ} \mathrm{C}\right)$ and two hour later in the tower $\left(16.7^{\circ} \mathrm{C}\right)$. In January the maximum air temperature is recorded at $03 \mathrm{PM}$ for both measuring points $\left(+0.3^{\circ} \mathrm{C}\right.$ and $-0.6^{\circ} \mathrm{C}$ respectively), while the minimum air temperature is recorded in the late morning at 08AM $\left(-5.6^{\circ} \mathrm{C}\right.$ and $-5.0^{\circ} \mathrm{C}$ respectively). In general, the air temperature values are higher at the ground level during the afternoon, being lower at the ground level during the morning. The daily air temperature amplitude decreases consistently at the tower level from $3.3^{\circ} \mathrm{C}$ in July to $1.5^{\circ} \mathrm{C}$ in January in comparison with the ground level.

We should mention that this is the first time we benefit from this sort of data, revealing such microclimatic information for the North-Eastern part of Romania. Even if this kind of air temperature variation near the ground is well known in the climate literature (Geiger, 1961), through the present study we offer a first concrete assessment in the region. Secondly, this kind of data offers the possibility to understand the distribution of the temperature within the Siret valley in its lowest part, since the weather station from this region are situated on the medium terraces of Siret river (Roman) or Bistrița river (Bacău). Therefore, based on the similarity of air temperature variations between Roman weather station and Tămășeni Tower (Table 1), we can estimate that, within the lowest part of Siret valley, the minimum mean air temperature during the cold semester is $0.5-1.0^{\circ} \mathrm{C}$ lower than those at the weather stations of Roman and also that the maximum mean air temperature during the warm semester is $1.0-1.5^{\circ} \mathrm{C}$ higher (Table 2). Also, well, this aspect can be assimilated in order to give a better idea on the distribution of air temperature along the river valleys in the north-east of Romania.

The microclimatic conditions near the ground, from the thermal point of view, are underlined by the hourly differences between ground and tower level (Fig. 4). During the warm semester, the air temperature is higher at the ground level from $6 \mathrm{AM}$ to $5 \mathrm{PM}$ (with maximum differences at $10 \mathrm{AM}$ ) with $4^{\circ} \mathrm{C}$ in July, $0.5^{\circ} \mathrm{C}$ in January and $2.0^{\circ} \mathrm{C}$ at annual level. On the contrary, during the cold semester the air temperature is lower at the ground level, from 7PM to 5AM, with the peak around 9 PM in July.

An important aspect of air temperature distribution within the study region is represented by the high frequency of air temperature inversions. These were classified in three classes taking into account the negative air temperature differences between the ground and tower levels: strong (negative difference $\left.>2^{\circ} \mathrm{C}\right)$, moderate $\left(>1^{\circ} \mathrm{C}\right)$ and total $\left(>0^{\circ} \mathrm{C}\right)$. The air temperature inversions are more common during autumn and winter. Hence, their frequency is directly related with the intensity of the radiative loss during the long nights between the equinoxes. The weak air temperature inversions are present along the year, with a frequency varying from a $7 \%$ during June and $25 \%$ in October (Fig. 5). 
Table 2. Mean annual hourly air temperature in Tămășeni Ground and Tămășeni Tower at 50 m altitude (March 2015 - February 2018)

\begin{tabular}{|c|c|c|c|c|c|c|c|c|c|c|}
\hline \multirow{2}{*}{ Hour } & \multicolumn{2}{|c|}{ Annual } & \multicolumn{2}{|c|}{ Warm semester } & \multicolumn{2}{|c|}{ July } & \multicolumn{2}{|c|}{ Cold Semester } & \multicolumn{2}{|c|}{ January } \\
\hline & Ground & Tower & Ground & Tower & Ground & Tower & Ground & Tower & Ground & Tower \\
\hline 0 & 7.5 & 8.6 & 14.0 & 15.3 & 17.5 & 19.9 & 1.0 & 1.9 & -4.6 & -3.8 \\
\hline 1 & 7.1 & 8.2 & 13.5 & 14.7 & 16.9 & 19.1 & 0.8 & 1.7 & -4.8 & -4.0 \\
\hline 2 & 6.7 & 7.8 & 13.0 & 14.1 & 16.2 & 18.5 & 0.5 & 1.4 & -5.0 & -4.2 \\
\hline 3 & 6.4 & 7.4 & 12.5 & 13.6 & 15.8 & 17.9 & 0.4 & 1.2 & -5.1 & -4.4 \\
\hline 4 & 6.2 & 7.1 & 12.2 & 13.2 & 15.4 & 17.3 & 0.2 & 1.0 & -5.3 & -4.6 \\
\hline 5 & 6.1 & 6.9 & 12.2 & 13.1 & 15.6 & 16.9 & 0.0 & 0.8 & -5.4 & -4.8 \\
\hline 6 & 6.6 & 7.1 & 13.2 & 13.4 & 16.9 & 16.7 & 0.0 & 0.8 & -5.6 & -4.9 \\
\hline 7 & 7.7 & 7.6 & 15.1 & 14.5 & 19.2 & 17.1 & 0.3 & 0.8 & -5.6 & -4.9 \\
\hline 8 & 9.3 & 8.6 & 17.5 & 16.0 & 21.7 & 18.3 & 1.1 & 1.1 & -5.6 & -5.0 \\
\hline 9 & 11.4 & 9.7 & 20.1 & 17.6 & 24.5 & 19.9 & 2.7 & 1.9 & -5.4 & -4.9 \\
\hline 10 & 13.0 & 11.0 & 21.8 & 19.1 & 26.2 & 21.4 & 4.1 & 2.9 & -4.2 & -4.4 \\
\hline 11 & 14.1 & 12.2 & 23.1 & 20.4 & 27.3 & 22.8 & 5.2 & 4.1 & -2.7 & -3.6 \\
\hline 12 & 14.9 & 13.4 & 23.9 & 21.7 & 28.2 & 24.0 & 6.0 & 5.2 & -1.6 & -2.5 \\
\hline 13 & 15.6 & 14.4 & 24.5 & 22.7 & 28.8 & 25.2 & 6.7 & 6.0 & -0.7 & -1.5 \\
\hline 14 & 15.9 & 14.7 & 24.8 & 23.2 & 29.3 & 26.5 & 7.0 & 6.2 & 0.0 & -0.8 \\
\hline 15 & 15.7 & 14.8 & 24.8 & 23.4 & 28.9 & 27.1 & 6.6 & 6.1 & 0.3 & -0.6 \\
\hline 16 & 15.1 & 14.4 & 24.3 & 23.2 & 28.7 & 27.3 & 5.8 & 5.5 & -0.2 & -0.7 \\
\hline 17 & 13.9 & 13.7 & 23.3 & 22.7 & 27.8 & 27.2 & 4.5 & 4.8 & -1.1 & -1.3 \\
\hline 18 & 12.4 & 12.9 & 21.5 & 21.7 & 26.1 & 26.9 & 3.4 & 4.1 & -2.3 & -2.0 \\
\hline 19 & 11.1 & 12.0 & 19.4 & 20.3 & 23.9 & 26.1 & 2.7 & 3.6 & -3.0 & -2.3 \\
\hline 20 & 9.9 & 11.0 & 17.6 & 18.9 & 21.7 & 24.8 & 2.3 & 3.2 & -3.4 & -2.8 \\
\hline 21 & 9.1 & 10.3 & 16.3 & 17.8 & 20.1 & 23.1 & 1.9 & 2.9 & -3.8 & -2.9 \\
\hline 22 & 8.5 & 9.7 & 15.4 & 16.9 & 19.0 & 21.9 & 1.6 & 2.5 & -4.1 & -3.2 \\
\hline 23 & 8.0 & 9.2 & 14.7 & 16.1 & 18.2 & 20.8 & 1.2 & 2.2 & -4.3 & -3.5 \\
\hline Mean & 10.5 & 10.5 & 18.3 & 18.1 & 22.4 & 22.0 & 2.7 & 2.3 & -3.4 & -3.2 \\
\hline Max & 15.9 & 14.8 & 24.8 & 23.4 & 29.3 & 27.3 & 7.0 & 6.2 & 0.3 & -0.6 \\
\hline Min & 6.1 & 6.9 & 12.2 & 13.1 & 15.4 & 16.7 & 0.0 & 0.8 & -5.6 & -5.0 \\
\hline$\Delta$ & 9.8 & 7.8 & 12.7 & 10.4 & 13.9 & 10.6 & 7.0 & 5.4 & 5.9 & 4.4 \\
\hline
\end{tabular}

As well, moderate inversions are present only between August and April (with a maximum by $11 \%$ in October), while strong inversions are rare and specific for the interval between September and February (with a maximum by only $3 \%$ in November).

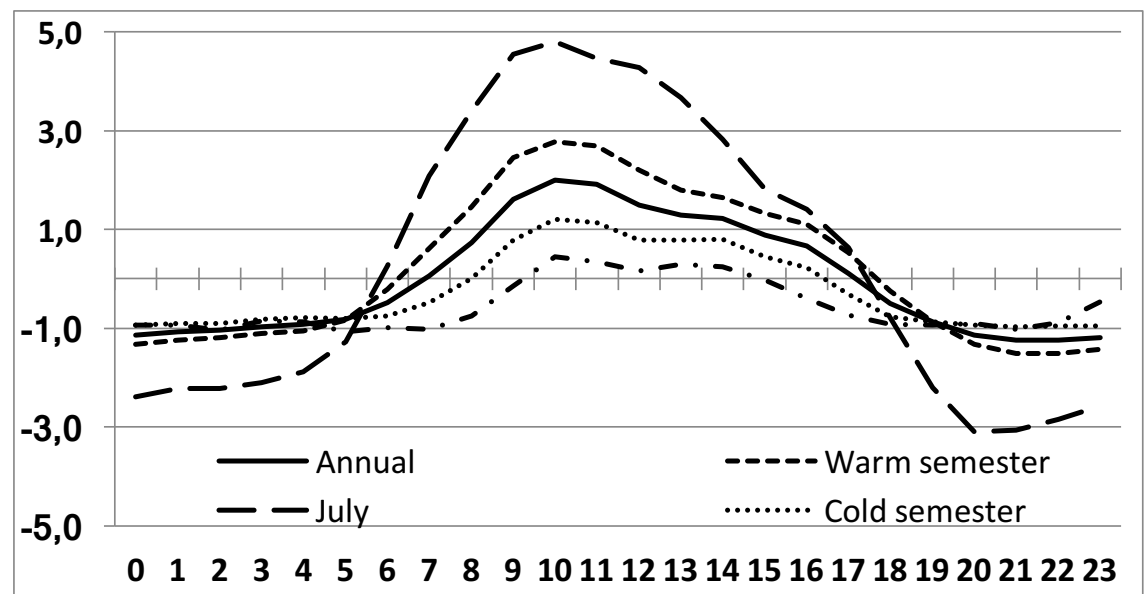

Fig. 4. Mean hourly air temperature difference $\left({ }^{\circ} \mathrm{C}\right)$ between Tămășeni Ground and Tămășeni Tower (March 2015 - February 2018) 
Using the minimum daily air temperature, the air temperature inversions are dominant (299 days/year). The strong air temperature inversions are present in 126 days (Table 3) while the weak inversions are frequent even for maximum air temperature (51 days). In general, it is important to notice that the air temperature inversions are present during half of the year (180.3 days) considering the mean air temperature.

Using GWT classification presented in Fig. 2 we analyzed which synoptic patterns induce more frequently air temperature inversions (Fig. 6) in the study region. Besides the fact that air temperature inversions develop under anticyclonic conditions (\#18), their occurrence can be noticed during north-westerly/northerly (\#11,\#12,) or north-easterly/easterly (\#5,\#6) air mass advections as well.

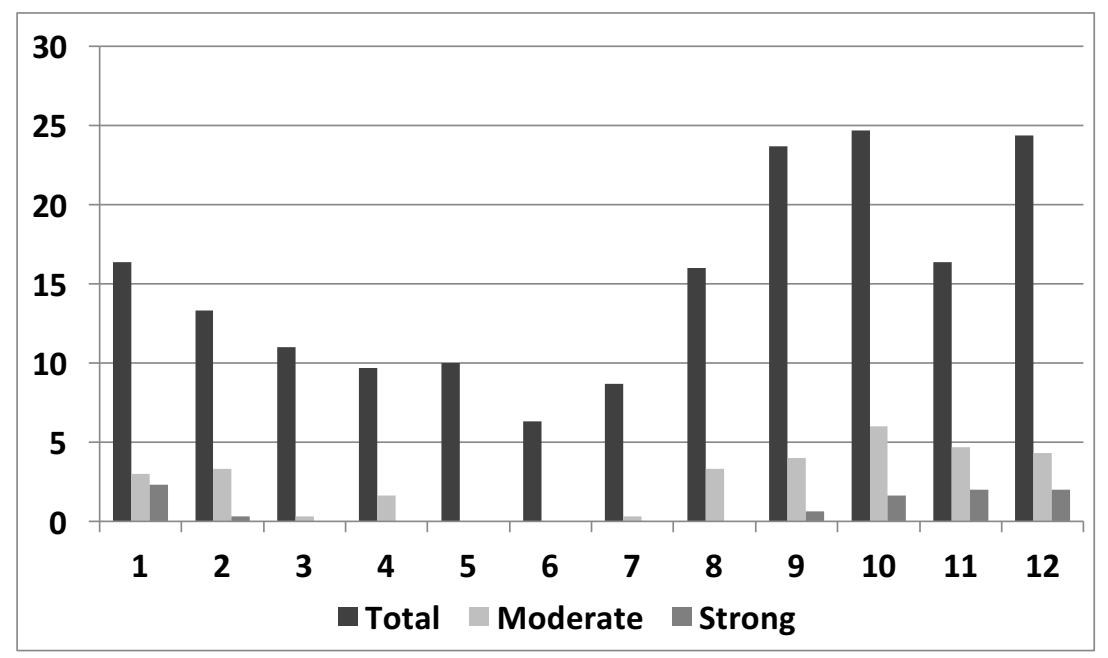

Fig. 5. Monthly frequency (\%) of air temperature inversions between TămășeniGround and Tămășeni Tower (March 2015 - February 2018)

Most probably, the cold air brought by these air mass advections forces the lifting of the preexisting warm air into certain altitude, leading to air temperature inversions, knowing the fact that that the North-East region of Romania is freely exposed to these cold air advections (Apostol and Sfîcă, 2011).

Table 3. Number of days with daily air temperature inversions between Tămășeni Ground and Tămășeni Tower (March 2015 - February 2018)

\begin{tabular}{|c|c|c|c|c|}
\hline Inversion type & Intensity $\left({ }^{\circ} \mathrm{C}\right) / 50 \mathrm{~m}$ & $\mathrm{Tm}$ & $\mathrm{Tx}$ & $\mathrm{Tn}$ \\
\hline Strong & $>2^{\circ} \mathrm{C}$ & 9.0 & 3.0 & 126.0 \\
\hline Moderate and strong & $>1{ }^{\circ} \mathrm{C}$ & 40.0 & 11.7 & 218.0 \\
\hline Total & $>0{ }^{\circ} \mathrm{C}$ & 180.3 & 51.0 & 299.0 \\
\hline
\end{tabular}

On the contrary, the air temperature inversions occur only accidentally during southerly/south-easterly or south-westerly (\#7, \#8,\#15), which is surprising since they are known to induce intense air temperature inversions at regional scale (Sfícă et al., 2018). 


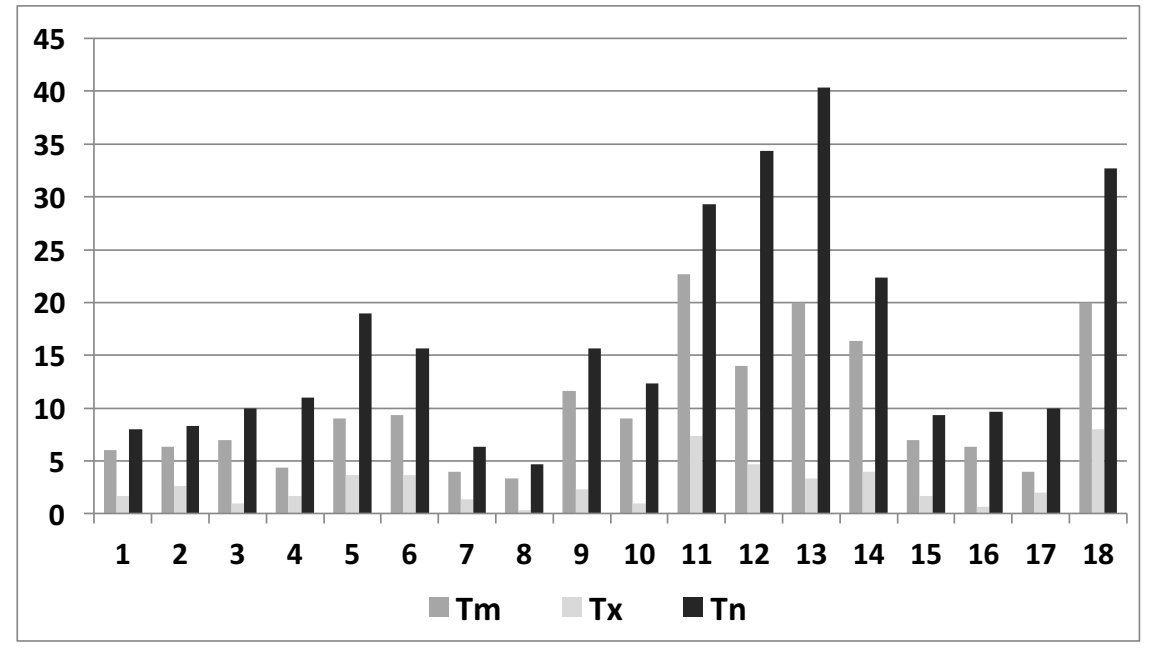

Fig. 6. Number of days with air temperature inversions between Tămășeni Ground and

Tămășeni Tower altitude (March 2015 - February 2018)for each Gross Wetter Type atmospheric circulation(air temperature inversions identified using daily mean - Tm, daily maximum - Tx and daily minimum - Tn air temperature)

Most probably, in the Siret Corridor, the lower part of the valley (below $50 \mathrm{~m}$ ) remains within the cold air during these types of advections, while the warmer air is advected at higher altitudes above. Overall, the anticyclones centered at the north of Romania and extended also over the study region (\#13) determine commonly the occurrence of air temperature inversions, while the prevalent cyclonic conditions are favorable for a normal air temperature stratification.

\section{CONCLUSIONS}

The current study contributes to the understanding of air temperature variations near the ground within the lowest part of Siret valley near the national weather station of Roman. We have observed that in the proximity of the ground the air temperature is led by insolation during the day/warm season and by the radiative cooling during the night/cold season.

Also, the results bring an idea about the differences in air temperature between Roman weather station and the lowest part of Siret valley. In winter, the air temperature is lower especially concerning the minimum values in the valley, while in summer the values are higher.

Beside anticyclonic conditions which are expected to favor the air temperature inversions development, the northerly and north-westerly atmospheric circulations have been noted to have an important contribution to this kind of atmospheric phenomena. 


\section{REFERENCES}

1. Andrei, N. (1937), Climatologia Moldovei subcarpatice. Extras din AnuarulLiceului de băieți (1935-1936), Tipografia Lumina, Piatra Neamț.

2. Apăvăloae, M., Pîrvulescu, I., Apostol, L. (1987), Caracteristici ale inversiunilor termice din Podișul Fălticeni. Lucrările "Seminarului geographic Dimitrie Cantemir", 8.

3. Apostol, L.(2004), Clima Subcarpaților Moldovei. Ed. Universității din Suceava.

4. Apostol L, Sfîcă L. (2011), Topoclimatic wind pe culiarities induced by the Siret corridor morphology. Prace i Studia Geograficzne, T. 47, ss. 483-491, Warsaw, Polonia.

5. Beck, C. (2000), Zirkulations dynamischeVariabilität im Bereich NordatlantikEuropa seit 1780 - dissertation. Selbstverlag des Instituts für Geographie, Würzburg.

6. Beck, C., Jacobeit, J., Jones, P.D. (2007), Frequency and within-type variations of large-scale circulation types and their effects on low-frequency climate variability in Central Europe since 1780, International Journal of Climology, 27: 473-491, doi: $10.1002 /$ joc. 1410

7. Dee, D. P., Uppala, S. M., Simmons, A. J., Berrisford, P., Poli, P., Kobayashi, S., and Coauthors (2011), The ERA - Interim reanalysis: Configuration and performance of the data assimilation 608 system.Quarterly Journalof Royal Meteorological Society, 137, 656, 553-597.

8. Geiger, R., (1961), Das Klima der bodennahen Luftschicht. Ein Lehrbuch der mikroklimatologie, Friedrich Vieweg\&Son, Braunschweig.

9. Ichim, P., Apostol, L., Sfîcă, L., Kadhim-Abid, A.L., Istrate, V., (2013), Frequency of thermal inversions between Siret and Prut rivers in 2013, Present Environment and Sustainable Development, 8 (2): 267-284, doi: 10.2478/pesd-2014-0040.

10. Philipp, A., Bartholy, J., Beck, C., Erpicum, M., Esteban, P., Fettweis, X. and Coauthors, (2010), Cost733cat-A database of weather and circulation type classifications.Physics and Chemestry of the 750 Earth, Parts A/B/C, 35, 9-12, 360-373.

11. Sfîcă, L., (2015), Clima Culoarului Siretului și a regiunilor limitrofe, Editura Universității “AlexandruIoanCuza" din Iași.

12. Sfîcă, L., Nicuriuc, I., Niţă, A.(2019), Boundary Layer Temperature Stratification as Result of Atmospheric Circulation Within the Western Side of Braşov Depression, 2019 "Air and Water - Components ofthe Environment" Conference Proceedings, Cluj-Napoca, Romania, p. 53-64, DOI: 10.24193/AWC2019_06.

13.*** (1966), Climatological Atlas of Romania, București,InstitutulMeteorologic.

14. www.meteomanz.com 